\title{
CORRIGENDUM
}

\section{Visual Conversations in Art and Archaeology: Images of Mitra, by Philippa Adrych, Robert Bracey, Dominic Dalglish, Stefanie Lenk \& Rachel Wood, 2017. Oxford: Oxford University Press; ISBN 978-0-19-879253-6 hardback $£ 30.00 \& \$ 50.00 ; 208$ pp, 79 b/w figs - CORRIGENDUM}

doi:10.1017/S0959774317000932, published online for McDonald Institute of Archaeological Research by Cambridge University Press, 8 January 2018.

The above book review (Walsh 2018) was published with an error in the title. 'Mitra' should be spelled 'Mithra'. The author apologises for the error. The original book review has been corrected.

\section{Reference}

Walsh, D. (2018). Visual Conversations in Art and Archaeology: Images of Mithra, by Philippa Adrych, Robert Bracey, Dominic Dalglish, Stefanie Lenk \& Rachel Wood, 2017. Oxford: Oxford University Press; ISBN 978-0-19-879253-6 hardback £30.00\& \$50.00; 208 pp, $79 \mathrm{~b} / \mathrm{w}$ figs. Cambridge Archaeological Journal, $1-2$. 